\title{
PENGARUH PENDEKATAN SAINTIFIK BERBANTUAN MEDIA GAMBAR TERHADAP HASIL BELAJAR IPA
}

\author{
Ni Luh Putu Lovita Loka', I Nengah Suadnyana², \\ I. B. Surya Manuaba ${ }^{3}$ \\ ${ }^{123}$ Jurusan Pendidikan Guru Sekolah Dasar, FIP \\ Universitas Pendidikan Ganesha \\ Singaraja, Indonesia \\ e-mail: lovita.loka001@gmail.com ${ }^{1}$, inengah.suadnyana@undiksha.ac.id ${ }^{2}$, \\ idabagussurya.manuaba@undiksha.ac.id ${ }^{3}$
}

\begin{abstract}
Abstrak
Penelitian ini bertujuan untuk mengetahui perbedaan hasil belajar IPA antara kelompok siswa yang dibelajarkan melalui pendekatan saintifik berbantuan media gambar dan kelompok siswa yang dibelajarkan melalui pembelajaran konvensional pada siswa kelas IV SD Gugus III Abiansemal Tahun Ajaran 2017/2018. Jenis penelitian ini merupakan eksperimen semu dengan menggunakan desain penelitian non-equivalent control group design. Populasi dari penelitian ini adalah seluruh siswa kelas IV SD Gugus III Abiansemal Tahun Ajaran 2017/2018 dengan jumlah siswa 197 orang. Sampel ditentukan dengan random sampling dengan mengacak kelas. Sampel dalam penelitian ini adalah kelas IV SD No. 4 Bongkasa sebagai kelompok eksperimen dan kelas IV SD No. 3 Bongkasa sebagai kelompok kontrol. Data hasil belajar IPA dikumpulkan dengan instrumen berupa tes objektif bentuk pilihan ganda biasa. Data hasil belajar IPA kemudian dianalisis dengan uji-t. Hasil analisis menunjukan bahwa terdapat perbedaan yang signifikan hasil belajar IPA antara kelompok siswa yang dibelajarkan melalui pendekatan saintifik berbantuan media gambar dengan kelompok siswa yang dibelajarkan melalui pembelajaran konvensional pada siswa kelas IV SD Gugus III Abiansemal Kecamatan Abiansemal Tahun Ajaran 2017/2018. Hal tersebut dibuktikan dengan hasil $t_{\text {hitumg }}=3,193>t_{\text {tabel }}=$ 2,000. Demikian pula nilai rerata hasil belajar IPA siswa kelompok eksperimen $\bar{X}=75,37>\bar{X}=$ 66,97rerata hasil belajar IPA siswa kelompok control. Dengan demikian dapat disimpulkan bahwa penerapan pendekatan saintifik berbantuan media gambar berpengaruh terhadap hasil belajar IPA siswa kelas IV SD Gugus III Abiansemal Kecamatan Abiansemal Tahun Ajaran 2017/2018.
\end{abstract}

Kata kunci: Saintifik, Media Gambar, Hasil Belajar IPA

\section{Abstract}

Researchers aim to find out the difference of the results between groups of students learning the IPA dibelajarkan through scientific approach to image and media assisted the Group of students that dibelajarkan through the conventional learning at grade IV ELEMENTARY SCHOOL Cluster III Abiansemal school year 2017/2018. This type of research is quasi experiment with using design research of non-equivalent control group design. The population of this research is the whole grade IV ELEMENTARY Cluster III Abiansemal 2017/2018 s with a total of 197 people. The sample is determined by random sampling with scrambles class. The sample in this research are class IV ELEMENTARY SCHOOL No. 4 Bongkasa as a group of experiments and class IV ELEMENTARY SCHOOL No. 3 Bongkasa as a control group. Results of the study data collected with IPA instrument in the form of an objective test is multiple choice form. Learning outcome data are then analyzed with the IPA-t test. The results of the analysis show that there is a significant difference between the IPA learning results of students who dibelajarkan through scientific approach assisted media images with the dibelajarkan groups of students through the conventional learning at grade IV ELEMENTARY Cluster III Abiansemal Sub Abiansemal school year 2017/2018. It is proved by the results of a thitumg $=$ ttabel $>3.193=2.000$. Similarly the average value of the results of the experimental group of students learning the IPA $=75.37>=66$, 97rerata the results of learning IPA students group control. Thus it can be concluded that the application of the scientific approach to image media-aided results learn IPA grade IV ELEMENTARY Cluster III Abiansemal Sub Abiansemal school year 2017/2018.

Keywords: Scientific, Media Images, The Result of Learning the IPA. 


\section{Pendahuluan}

Peningkatan kualitas pendidikan di Indonesia diupayakan oleh pemerintah dengan melaksanakan penyempurnaan-penyempurnaan pada setiap perangkat pendidikan. Salah satu perangkat pendidikan yang terus mengalami perkembangan untuk meningkatkan kualitas pendidikan adalah kurikulum.

Menurut Sufairoh (2016) Pada hakikatnya pengembangan kurikulum itu merupakan usaha untuk mencari bagaimana rencana dan pengaturan mengenai tujuan, isi, dan bahan pelajaran serta cara yang digunakan sebagai pedoman penyelenggaraan kegiatan pembelajaran yang sesuai dengan perkembangan dan kebutuhan untuk mencapai tujuan tertentu dalam suatu lembaga. Pengembangan kurikulum di arahkan pada pencapaian nilainilai umum, konsep-konsep, masalah dan keterampilan yang akan menjadi isi kurikulum yang disusun dengan fokus pada nilai-nilai tadi. Adapun selain berpedoman pada landasanlandasan yang ada, pengembangan kurikulum juga berpijak pada prinsip-prinsip pengembangan kurikulum. Kurikulum menurut Undang-undang No. 20 tahun 2003 tentang Sistem Pendidikan Nasional pasal 1 ayat (19) adalah seperangkat rencana dan pengaturan mengenai tujuan, isi dan bahan pelajaran serta cara yang digunakan sebagai pedoman penyelenggaraan kegiatan pembelajaran untuk mencapai tujuan pendidikan tertentu. Penyempurnaan kurikulum yang terjadi yaitu penyempurnaan dari Kurikulum Tingkat Satuan Pendidikan (KTSP) menjadi Kurikulum 2013.

Karakteristik kurikulum 2013 adalah menggunakan pendekatan saintifik yang diberikan melalui pembelajaran tematik. Menurut Kemdikbud, proses pembelajaran pada Kurikulum 2013 untuk semua jenjang dilaksanakan dengan menggunakan pendekatan ilmiah (scientific appoach). Proses pembelajaran menyentuh tiga ranah, yaitu sikap, pengetahuan, dan keterampilan.Dalam proses pembelajaran berbasis pendekatan saintifik, hasil akhirnya adalah peningkatan dan keseimbangan antara kemampuan untuk menjadi manusia yang baik (soft skills) dan manusia yang memiliki kecakapan serta pengetahuan. Permendikbud no 57 tahun 2014 lampiran 1 mengemukan bahwa,

"Kurikulum 2013 bertujuan untuk mempersiapkan manusia Indonesia agar memiliki kemampuan hidup sebagai pribadi dan warga Negara yang beriman, prodiktif, kreatif, inovatif, dan afektif serta mampu berkontribusi pada kehidupan bermasyarakat, berbangsa, bernegara, dan peradaban dunia".

Dalam kurikulum 2013 siswa dituntun melalui beberapa proses secara aktif mencari, mengola, mengkonstruksi, dan menerapkan pengetahuan. Maka sangat diperlukan upaya inovasi guru dalam mensiasati pembelajaran di kelas. Kenyataan di lapangan masih banyak guru yang berpaku pada buku yang hanya memberikan penugasan dalam mengerjakan siswa, sehingga pembelajaran terkesan masih dominan guru. Ini menunjukan adanya kesenjangan antara kenyataan di lapangan dan harapan sesuai dengan kurikulum 2013. Namun pada SD Gugus III Abiansemal Kecamatan Abiansemal saat ini masih menggunakan kurikulum KTSP

Dari hasil observasi yang dilakukan pada hari 23 Januari 2018 dengan wali kelas IV di masing-masing SD Gugus III Abiansemal tahun ajaran 2017/2018, untuk hasil belajar IPA diperoleh dari hasil rapot semester I, kriteria ketuntasan minimal (KKM) yang ditetapkan sekolah untuk mata pelajaran IPA adalah 80, dari 197 siswa yang mendapatkan nilai di atas KKM sebanyak 108 atau 56,25\% siswa yang sudah mencapai nilai yang diharapkan sedangkan siswa yang masih dibawah KKM sebanyak 84 atau 43,75\% siswa yang belum mampu menunjukan hasil belajar yang baik. Berdasarkan hal tersebut, tentu saja disebabkan oleh banyak faktor, salah satunya yaitu model yang digunakan kurang inovatif dan bervariasi sehingga menyebabkan siswa tidak berpartisipasi aktif dalam mengikuti proses pembelajaran.

Pelaksanaan pembelajaran di kelas perlu didesain secara kreatif dan inovatif dengan memperhatikan karakteristik perkembangan siswa kelas IV SD Gugus III Abiansemal Kecamatan Abiansemal. Dari permasalahan tersebut dipandang perlu adanya inovasi dalam pembelajaran yakni pembelajaran yang mengutamakan penguasaan kompetensi, berpusat 
pada siswa, memberikan pengalaman belajar, dan relevan dengan kehidupan nyata. Salah satu inovasi yang dimaksud yakni dengan menerapkan Pendekatan pembelajaran saintifik berbantuan media gambar sebagai media belajar atau sumber belajar.

Menurut Bermawi (2016) pendekatan saintifik memberikan pemahaman kepada peserta didik mengenal, memahami barbagai materi menggunakan pendekatan ilmiah bahwa informasi berasal dari mana saja, kapan saja dan tidak bergantung dari informasi searah dari guru. Kondisi pembelajaran diharapkan mengarahkan peserta didik dalam mencari tahu dari berbagai sumber melaui observasi bukan hanya diberi tahu. Menurut Permatasari (2014) Pendekatan saintifik berasal dari kata saint yang berarti ilmu. Maka pendekatan saintifik adalah pendekatan keilmuan yang bersifat logis dan sistematis. Dalam prosesnya diawali dari siswa menanya, karena ada objek yang dilihat dan didengar maka siswa merespon sehingga muncul kegiatan bertanya, ketika guru menyampaikan atau menjawab pertanyaan dari siswa maka nantinya akan dikaitkan dengan materi yang diajarkan. Kemudian siswa diajak untuk menyelesaikan persoalan-persoalan dengan cara berkolaborasi dalam suatu kelompok misalnya dengan diskusi antar siswa satu dengan lainnya. Menurut Setiawan (2017) pendekatan pembelajaran saintifik adalah proses pembelajaran yang dirancang agar peserta didik secara aktif mengonstruk konsep, hukum atau prinsip melalui tahapan-tahapan mengamati, menanya, menalar, mencoba, membentuk jejaring untuk semua mata pelajaran. Menurut Hamidah (2015) Pendekatan saintifik merupakan proses mendekati penahaman pembelajaran secara ilmiah dengan menerapkan konsepkonsep penelitian ilmiah menuju pembelajaran yang bersifat empiris, aktif, kreatif dan efektif. Pendekatan saintifik adalah proses pembelajaran yang dirancang sedemikian rupa agar peserta didik secara aktif membangun konsep, prinsip, melalui mengamati, menanya, mengumpulkan informasi/melakukan eksperimen, mengasosiasikan/mengolah informasi, dan mengkomunikasikan (Permendikbud no 81 A Tahun 2013 lampiran IV).

Pembelajaran dengan pendekatan saintifik berbantuan media gambar sangat cocok diterapkan untuk mata pelajaran IPA. Karena selama ini IPA hanya dibelajarkan dengan berpatokan pada buku pegangan sehingga kurang menarik bagi siswa. Pendekatan saintifik berbantuan media gambar membuat pembelajaran IPA menjadi lebih menarik dan bermakna karena siswa diberikan kesempatan untuk membangun pengetahuannya sendiri melalui berbagai kegiatan sehingga pengetahuan yang didapat oleh siswa tidak bersifat hapalan semata. Hal ini membuat pengetahuan yang diterima tidak cepat dilupakan oleh siswa sehingga hasil belajar menjadi optimal. Siswa belajar untuk mengemukakan pendapat, mendengarkan opini orang lain, mencari informasi, menyadari adanya perbedaan, membangun empati dan pengertian, untuk kemudian mengambil kesimpulan.

Berdasarkan uraian tersebut, secara teoritis Pendekatan saintifik berbantuan media gambar diduga berpengaruh terhadap hasil belajar IPA, tetapi secara empiris perlu dibuktikan menggunakan penelitian yang berjudul "pengaruh pendekatan saintifik berbantuan media gambar terhadap hasil belajar IPA SD Gugus III Abiansemal Kecamatan Abiansemal.

\section{Metode}

Penelitian ini adalah penelitian eksperimen dengan menggunakan desain eksperimen semu (Quasy Exsperimen). Sugiyono (2012:114) menyatakan "Desain ini memiliki kelompok kontrol, tetapi tidak bisa sepenunya mengontrol variabel-variabel luar yang mempengaruhi pelaksanaan eksperimen". Hal ini dikarenakan kemampuan penelitian dalam mengamati prilaku siswa sangat terbatas terutama ketika siswa berada di luar sekolah (rumah), peneliti juga tidak memiliki kemampuan untuk mengetahui persepsi siswa terhadap perlakuan secara pasti. Rancangan eksperimen semu yang akan digunakan dalam penelitian ini adalah "Nonequilevalent Control Group Design". Penelitian ini bertujuan untuk mengetahui pengaruh pendekatan saintifik berbantuan media gambar terhadap hasil belajar IPA siswa. Rancangan penelitian yang akan digunakan pada penelitian ini digambarkan sebagai berikut: 


\begin{tabular}{|lrr|}
\hline O1 & X & O2 \\
\hline O3 & & O4 \\
\hline
\end{tabular}

(Sumber :Sugiyono, 2012: 116)

\section{Gambar 1. Rancangan kelompok Non-equivalent}

Setyosari (2015: 221) menyatakan, populasi merupakan keseluruhan dari objek, orang, peristiwa, atau sejenisnya yang menjadi perhatian dan kajian dalam penelitian.

Populasi dalam penelitian ini adalah siswa kelas IV SD Negeri yang terdapat pada Gugus III Abiansemal Kecamatan Abiansemal Tahun Ajaran 2017/2018 terdapat 6 SD yaitu SD No 1 Bongklasa, SD No 2 Bongkasa, SD No 3 Bongkasa, SD No 4 Bongkasa, SD No 1 Bongkasa Pertiwi, SD No 2 Bongkasa Pertiwi, yang berjumlah 197 siswa. Teknik pengambilan sample pada penelitian ini adalah Random Sampling yang dirandom kelasnya, sehingga setiap kelas mendapatkan peluang yang sama untuk menjadi sample penelitian. Sehingga setiap kelas mendapatkan peluang yang sama untuk menjadi sampel penelitian. Sugiyono, (2012: 132) menyatakan teknik pengambilan sampel adalah random, maka setiap anggota populasi mempunyai peluang sama untuk dipilih menjadi anggota sampel, pengambilan sampel secara random/acak dapat dilakukan dengan undian. Sedangkan Agung (2014: 71) menyatakan, " sampling random merupakan cara pengambilan sampel dengan memberikan kesempatan yang sama kepada anggota populasi untuk diambil menjadi anggota sampel". Setelah melakukan proses pengundian dari setiap siswa kelas IV pada 6 sekolah maka mendapatkan dua kelas sample. Setelah itu kedua kelas sample tersebut diuji kesetaraanya secara emperis dengan menggunakan data nilai siswa setelah mengikuti pre-test. Dalam penelitian ini pre-test digunakan untuk menyetarakan kelas. Teknik yang digunakan dalam penyetaraan kelas adalah teknik matching.

Darmadi (2014:234) menyatakan, Teknik matching adalah suatu teknik untuk menyeragamkan kelas pada suatu variabel atau lebih yang oleh peneliti sudah diidentifikasi memiliki hubungan yang erat dengan penampilan (performance) variabel tidak bebas. Untuk masing-masing subjek yang ada, peneliti berusaha mencari subjek yang lain yang sama atau nilainya mirip pada variabel control. Jika terdapat subjek yang tidak mendapatkan jodoh maka harus dihilangkan dalam penelitian.

Setelah mendapatkan nilai pre-test dari kedua sample, maka nilai dari kedua sample tersebut disetarakan dengan teknik matching. Ini dilakukan dengan cara menjodohkan nilai pre-test siswa dari kedua sample. Jika terdapat nilai siswa yang tidak mendapatkan pasangan maka siswa tersebut tetap diikutkan dalam proses pemberian perlakuan saat penelitian, akan tetapi siswa tersebut tidak diikutkan sebagai sample. Ini dilakukan agar tidak mengganggu psikologi siswa. Setelah diketahui kedua sample setara, selanjutnya peneliti melakukan pengundian lagi dari dua sample yang setara tersebut untuk memilih mana sekolah yang digunakan sebagai kelas kontrol dan kelas eksperimen. Setelah mengadakan random maka mendapatkan dua sample yakni kelas IV SD No. 3 Bongkasa dan kelas IV SD No. 4 Bongkasa. Kelas IV di SD No. 3 Bongkasa berjumlah 35 dan kelas IV Sd No 4 Bongkasa berjumlah 36. Lalu memberikan pre-test pada kedua kelas tersebut pada tanggal 13 April 2018. Data nilai siswa di Matching dilakukan pada dua kelas tersebut. Setelah di Matching hasilnya 32 siswa terbukti memiliki kemampuan yang setara secara akademik. Sehingga sample yang diteliti dalam penelitian ini hanya 64 sample. Analisis nilai pre-test siswa dengan matching Dengan kriteria, jika harga $t_{\text {hitung }}<t_{\text {tabel }}$ maka $\mathrm{H}_{0}$ diterima dan $\mathrm{H}_{\mathrm{a}}$ ditolak. Sebaliknya jika harga $t_{\text {hitung }}>t_{\text {tabel }}$ maka $\mathrm{H}_{0}$ ditolak dan $\mathrm{H}_{\mathrm{a}}$ diterima. Pengujian dilakukan pada taraf signifikansi $5 \%$ dengan $\mathrm{dk}=\mathrm{n}_{1}+\mathrm{n}_{2}-2$.

Sebelum dilakukan uji kesetaraan, terlebih dahulu dilakukan uji prasyarat analisis yang meliputi uji normalitas sebaran data dan uji homogenitas varians. Uji normalitas kedua sampel dilakukan menggunakan analisis Chi Kuadrat. Adapun rekapitulasi hasil uji 
normalitas data pretest hasil belajar IPA pada siswa kelas IV SD Gugus III Abiansemal Kecamatan Abiansemal. Hasil dari perhitungan uji kesetaraan kelas sampel yang digunakan disajikan pada tabel berikut.

a. Uji Normalitas

Untuk mengetahui apakah sebaran data skor hasil belajar IPA siswa masing-masing kelompok berdistribusi normal atau tidak. Uji normalitas untuk skor penguasaan kompetensi pengetahuan IPA siswa dalam penelitian ini menggunakan teknik Chi-Kuadrat dengan rumus:

$$
x^{2}=\sum \frac{\left(f_{0}-f_{h}\right)^{2}}{f_{h}}
$$

(Sugiyono, 2014:241)

Keterangan:

$f_{o}=$ Frekuensi Observasi

$f_{h}=$ Frekuensi Harapan

Kriteria pengujian adalah bila harga Chi Kuadrat hitung lebih kecil atau sama dengan harga Chi Kuadrat tabel $\left(x_{h}^{2} \leq x_{t}{ }^{2}\right)$ maka distribusi data dinyatakan normal, dan apabila harga Chi-Kuadrathitung lebih besar atau ama dengan harga Chi-Kuadrattabel $\left(x_{h}^{2}>x_{t}{ }^{2}\right)$, dengan taraf signifikansi $5 \%$ dan $\mathrm{dk}=(\mathrm{k}-1)$ maka distribusi data dinyatakan tidak normal.

b. Uji Homogenitas

Uji homogenitas digunakan untuk menguji apakah sebaran data tersebut homogen atau tidak, yaitu dengan membandingkan kedua variansnya. Uji homogenitas dapat dilakukan apabila kelompok data tersebut berdistribusi normal.

Uji homogenitas varians untuk kedua kelas digunakan uji F dengan menggunakan rumus sebagai berikut.

$$
F=\frac{\text { varian yang lebih besar }\left(S_{1}^{2}\right)}{\text { varian yang lebih } \operatorname{kecil}\left(S_{2}^{2}\right)}
$$

Keterangan:

$S_{1}^{2}=$ Variansyanglebihbesar

$S_{2}^{2}=$ Variansyang lebihkecil

(Sugiyono, 2014:275)

Kriteria pengujian, jika $F_{\text {hit }}<F_{\text {tabel }}$ maka sampel homogen dan jika $F_{\text {hit }}>F_{\text {tab }}$ maka data tidak homogen. Pengujian dilakukan pada taraf signifikansi $5 \%$ dengan derajat kebebasan untuk pembilang $n_{1}-1$ dan derajat kebebasan untuk penyebut $n_{2}-1$.

\section{Hasil dan Pembahasan}

Berdasarkan Uji normalitas sebaran data dilakukan pada kedua kelas, data yang meliputi data kelas yang dibelajarkan melalui pendekatan saintifk dan data kelas yang dibelajarkan melalui pembelajaran konvensional. Ini dilakukan untuk mengetahui sebaran data Uji normalitas data dilakukan dengan menggunakan analisis Chi-Kuadrat dengan rumus $X_{\text {hit }}^{2}=\sum_{i}^{n} \frac{\left(f_{0}-f_{e}\right)^{2}}{f e}$ dan ketentuan harga $\left(X^{2}\right.$ hitung $)$ yang diperoleh dibandingkan dengan harga 
$\left(\mathrm{X}_{\text {tabel }}^{2}\right)$ dengan derajat kebebasan $(\mathrm{db})=(\mathrm{k}-1)=(6-1)=5$ dan taraf signifikansi $5 \%$ $=11,070$.

Tabel 1. Hasil Uji Normalitas Sebaran Data Hasil Belajart IPA

\begin{tabular}{llrlc}
\hline No. & \multicolumn{1}{c}{ Sampel } & $\mathbf{X}^{2}{ }_{\text {itung }}$ & $\mathbf{X}_{\text {tabel }}^{2}$ & Kesimpulan \\
\hline 1. & $\begin{array}{l}\text { SD No 4 Bongkasa } \\
\text { Kelas Eksperimen }\end{array}$ & 5,59 & 11,070 & Normal \\
& $\begin{array}{l}\text { SD No 3 Bongkasa } \\
\text { Kelas Kontrol }\end{array}$ & 3,89 & 11,070 & Normal \\
\hline
\end{tabular}

Berdasarkan hasil uji normalitas kelompok eksperimen pada lampiran 21 pada halaman 164. Harga $\chi_{\text {hit }}^{2}$ yang diperoleh dari kelompok eksperimen $\chi_{\text {hit }}^{2}=\sum_{1}^{6} \frac{(f o-f e)^{2}}{f e}=5,59$. Harga tersebut kemudian dibandingkan dengan harga $X_{\text {tabel }}^{2}$ dengan $\mathrm{db}=5$ dan taraf signifikansi $5 \%$ sehingga diperoleh harga $X_{\text {tabel }}^{2}=11,070$. Tabel nilai-nilai chi-kuadrat dapat dilihat pada lampiran 27 pada halaman 206. Karena $X^{2}$ hitung $<X_{\text {tabel }}^{2}(5,59<11,070)$ maka $H_{0}$ diterima atau $\mathrm{H}_{\mathrm{a}}$ ditolak. Ini berarti sebaran data hasil belajar IPAkelompok eksperimen berdistribusi normal.

Setelah data ditanyakan normal, kemudian dilanjutkan dengan uji homogenitas varians. Homogenitas varians data hasil belajar IPA siswa dianalisis dengan uji $F$.

Tabel 2. Hasil Uji Homogenitas Varian Data Hasil Belajart IPA

\begin{tabular}{ccccccc}
\hline No. & Sampel & $\boldsymbol{S}_{1}{ }^{2}$ & $\boldsymbol{S}_{2}{ }^{2}$ & $\mathbf{F}_{\text {hitung }}$ & $\mathbf{F}_{\text {tabel }}$ & Kesimpulan \\
\hline 1 & $\begin{array}{c}\text { Kelompok } \\
\text { Eksperimen }\end{array}$ & 10,89 & 114,89 & & & \\
2 & Kelompok Kontrol & 10,33 & 106,86 & & & Homogen \\
\hline
\end{tabular}

Dari hasil analisis diperoleh $F_{\text {hitung }}$ sebesar 1,07. Selanjutnya $F_{\text {hitung }}$ akan dibandingkan dengan $F_{\text {table }}$ pada taraf signifikansi $5 \%$. Berdasarkan $F_{\text {table }}$ pada taraf signifikansi $5 \%$ dengan dk $\left(\mathrm{N}_{1}\right)=32-1=31$. Dan $\mathrm{dk}\left(\mathrm{N}_{2}\right)=32-1=31$. Didapatkan harga $\mathrm{F}_{\text {hitung }}$ sebesar $1,07 \mathrm{dan}$ $F_{\text {tabel }}$ sebesar 1,84. Hasil tersebut menunjukan $F_{\text {hitung }}<F_{\text {table, }}$, sehingga dapat disimpulkan bahwa data post-test hasil belajar IPA kelompok eksperimen dan kelompok control dinyatakan homogen.

Berdasarkan hasil uji prasyarat analisis data, diperoleh bahwa kedua kelompok yaitu kelompok eksperimen dan kelompok control berdistribusi normal dan homogeny. Setelah diperoleh hasil dari ujin prasyarat data maka dilanjutkan dengan uji hipotesis penelitian $\left(\mathrm{H}_{\mathrm{a}}\right)$ dan hipotesis nol $\left(\mathrm{H}_{\mathrm{o}}\right)$. penguji hipotesis pada penbelitian ini digunakan uji-t polled varian karena jumlah $n_{1}=n_{2}$ varian homogeny. Kriteria penguji hipotesis ialah jika $t_{\text {hitung }}<t_{\text {table }}$ maka $\mathrm{H}_{\mathrm{a}}$ ditolak dan $\mathrm{H}_{\mathrm{o}}$ diterima, sebaliknya $t_{\text {hitung }}>\mathrm{t}_{\text {table }}$ maka $\mathrm{H}_{\mathrm{a}}$ diterima dan $\mathrm{H}_{\mathrm{o}}$ ditolak. Data hasil uji-t dapat dilihat pada Tabel. 
Table 3. Hasil Analisis Data Hasil Belajar IPA

\begin{tabular}{|c|c|c|c|c|c|c|c|c|}
\hline No. & Sampel & $\mathbf{N}$ & Dk & $\bar{X}$ & $S^{2}$ & $t_{\text {hitung }}$ & $t_{\text {tabel }}$ & Keterangan \\
\hline 1. & $\begin{array}{l}\text { SD No } 4 \\
\text { Bongkasa } \\
\text { Kelas }\end{array}$ & 32 & 62 & 75,37 & 114,89 & & & \\
\hline 2. & $\begin{array}{l}\text { eksperimen } \\
\text { SD No } 3 \\
\text { Bongkasa } \\
\text { Kelas } \\
\text { control }\end{array}$ & 32 & & 66,97 & 106,86 & 3,193 & 2,000 & Setara \\
\hline
\end{tabular}

Berdasarkan hasil perhitungan uji-t diperoleh $t_{\text {hitung }}$ sebesar 3,193 dan $t_{\text {tabel }}$ sebesar 2,000 , dk 62 pada taraf signifikansi $5 \%$ ini berarti terdapat perbedaan yang signifikan hasil belajar IPA melalui pendekatan saintifik berbantuan media gambar dengan kelompok siswa yang dibelajarkan melalui pembelajaran konvensional.

Berdasarkan hasil analisis menggunakan uji-t diperoleh $t_{\text {hitung }}=3,193$ kemudian di bandingkan dengan $t_{\text {tabel }}$ dengan $\mathrm{dk} 62$ pada taraf signifikansi $5 \%$ diperoleh $t_{\text {tabel }}=2.000$. Karena $t_{\text {hitung }}=3,193>t_{\text {tabel }(\mathrm{\alpha}=0.05)}=2.000$, maka dapat disimpulkan bahwa hipotesis yang menyatakan terdapat perbedaan yang signifikan Hasil Belajar IPA kelompok yang di belajarkan dengan pendekatan saintifik berbantuan media gambar dan kelompok siswa yang dibelajarkan dengan pembelajaran konvensional pada siswa kelas IV SD Gugus III Abiansemal Kecamatan Abiansemal Tahun Ajaran 2017/2018.

Melihat perbandingan tersebut maka dalam penelitian ini membandingkan skor ratarata yang diperoleh dari kegiatan belajar tersebut. Maka diperoleh nilai rata-rata dari hasil pos-tes untuk kelompok eksperimen yang dibelajarkan melalui pendekatan saintifik berbantuan media gambar memproleh nilai rata-rata $=75,37$. Sedangkan pada kelompok kontrol yang dibelajarkan melalui pembelajaran konvensional memproleh nilai rata-rata= 66,97. Jadi penggunaan pendekatan saintifik berbantuan media gambar dalam penerapannya pada hasil belajar IPA dipandang lebih baik dari pmbelajran konvensional terlihat dari perolehan nilai rata-rata.

Pada materi sumber daya alam sedang berlangsung, siswa pada kelompok eksperimen kegiatan berlangsung sesuai dengan indikator yang menjadi fokus pada materi. Hal serupa juga berlangsung pada kelompok kontrol yang dibelajarkan melalui pembelajaran konvensional. Kegiatan belajar berjalan kondusif namun terlihat keaktifan siswa masing kurang, siswa terlihat pasif karena hanya menerima pembelajaran dengan menyimak, mencatat dan mendengarkan serta siswa masih terlihat kurang percaya diri ketika menjawab pertanyaan yang dipertanyakan kepada siswa.

Hal ini dikarenakan pendekatan saintifik mempunyai kelebihanya yaitu a) Proses pembelajaran lebih terpusat pada siswa sehingga memungkinkan siswa aktif dan kreaktif dalam pembelajaran, b). langkah-langkah pembelajarannya sistematis sehingga memudahkan guru untuk memanajemen pelaksanaan pembelajaran, c) memberi peluang guru untuk lebih kreatif dan mengajak siswa untuk aktif dengan berbagai sumber belajar, d) langkah-langkah pembelajaran melibatkan keterampilan proses sains dalam mengonstruksi konsep hukum atau prinsip, e) proses pembelajarannya melibatkan proses-proses kognitif yang potensial dalam merangsang perkembangan siswa, khususnya keterampilan berpikir tingkat tinggi siswa, f) dapat mengembangkan karakter siswa, g) penilaiannya mencakup semua aspek

$\mathrm{Hal}$ ini sangat penting, karena dengan dapat mengorelasikan meteri yang ditemukan dengan kehidupan nyata, bukan saja bagi siswa materi itu akan berfungsi secara fungsional, akan tetapi materi yang dipelajarinya akan tertanam erat dalam memori siswa, sehingga tidak mudah untuk dilupakan. Selain itu, siswa juga memperoleh pengetahuan dan keterampilan dari konteks yang terbatas sedikit demi sedikit, dan dari proses mengkonstruksi 
sendiri sebagai bekal untuk memecahkan masalah dalam kehidupannya sebagai anggoata masyarakat.

\section{Simpulan dan Saran}

Berdasarkan analisis data, diperoleh nilai rata-rata kelompok eksperimen lebih besar dari nilai rata-rata kelompok kontrol yaitu $X=75,37>X=66,97$. Selanjutnya melalui uji hipotesis diperoleh $\mathrm{T}_{\text {hitung }}=3,193$ dengan taraf signifiknsi $5 \%$ dan $\mathrm{dk}=62$ diperoleh harga $T_{\text {tabel }}=2,000$. Dengan demikian, $T_{\text {hitung }}=3,193>T_{\text {tabel }}(a=0,05,62)=2,000$ sehinga $H_{o}$ ditolak dan $\mathrm{H}_{a}$ diterima. Ini berarti terdapat perbedaan yang signifikan hasil belajar IPA antara kelompok siswa yang dibelajarkan menggunakn pendekatan saintifik berbantuan media gamabr dengan kelompok siswa yang dibelajarkan menggunakan pendekatan konvensional pada siswa kelas IV SD Gugus III Abiansemal Kecamatan Abiansemal Tahun Ajaran 2017/2018 . Berdasarkan perbedaan nilai rata-rata kedua kelompok dan hasil uji hipotesis, maka dapat disimpulkan bahwa penerapan dengan pendekatan saintifik berbantuan media gambar berpengaruh terhadap hasil belajar IPA pada siswa kelas IV SD Gugus III Abiansemal Kecamatan Abiansemal Tahun Ajaran 2017/2018.

Berdasarkan hasil penelitian, maka saran yang dapat diajukan sebagai berikut. 1) Kepada Guru, Berdasarkan temuan penelitian yang diperoleh, disarankan kepada guru agar lebih kreatif dan inovatif untuk memberikan fasilitas berupa sumber belajar dan kesempatan yang lebih besar bagi siswa pada pembelajaran dengan menggunakan model Picture and Picture berbasis portofolio sehingga tercipta pembelajaran bermakna untuk siswa. 2) Kepada Kepala Sekolah, Berdasarkan temuan penelitian, disarankan kepada kepala sekolah agar dapat menggunakan hasil penelitian ini sebagai pendukung sumber belajar guru dalam meningkatkan kualitas pembelajaran dengan menciptakan pembelajaran yang menggembirakan di sekolah sehingga sekolah mampu menghasilkan siswa berkualitas. 3) Kepada Peneliti Lain, Berdasarkan temuan penelitian, disarankan kepada peneliti agar hasil penelitian ini digunakan sebagai referensi untuk melaksanakan penelitian selanjutnya atau menemukan inovasi kegiatan pembelajaran lainnya yang bermakna bagi siswa.

\section{Daftar Rujukan}

Agung, Anak Agung Gede. 2014. Metodologi Penelitian Pendidikan.Singaraja :Undiksha.

Bermawi, Yoserizal, Tati Fauziah. 2016. Penerapan Pendekatan Saintifik dalam Pembelajaran di Sekolah Dasar Aceh Besar. Jurnal Pesona Dasar Vol. 2 No. 4 Hal 63-71. Tersedia Pada : http://www.jurnal.unsyiah.ac.id/PEAR/article/view/7533.

Dantes, Nyoman. 2012. Metode Penelitian. Yogyakarta: Andi.

Darmadi, Hamid. 2014. Metode Penelitian Pendidikan. Bandung: Alfabeta.

Emzir. 2013. Metodologi Penelitian Pendidikan kuanitatif\&Kualitatif Edisi Revisi. Jakarta: PT RajaGrafindo Persada.

Hamidah, Siti. 2015. Pendekatan Saintifik dalam Pembelajaran Teks Cerita Pendek pada Siswa Kelas VII Sekolah Menengah Pertama. Riksa Bahasa Vol. 1 No. 1 Hal. 107114. Tersedia Pada http://ejournal.upi.edu/index.php/RBSPs/article/viewFile/8706/pdf.

Kosasih. 2014. Strategi Belajar Dan Pembelajaran Implementasi Kurikulum 2013. Bandung: Yra ma Widya. 
Permatasari, Eka Aprilia. 2014. Implementasi Pendekatan Saintifik dalam Kurikulum 2013 Pada Pembelajaran Sejarah. Indonesian Journal of History education, Vol. 3 No. 1 Hal. 11-16. Tersedia Pada

https://journal.unnes.ac.id/sju/index.php/ijhe/article/view/3884.

Setiawan, Dika. 2013. Pendekatan Saintifik dan Penilaian Autentik untuk Meningkatkan Mutu Pembelajaran Pendidikan Agama Islam (Studi Penerapan Kurikulum 2013 Pendidikan Agama Islam (PAI) di SD Muhammadiyah Sapen Yogyakarta). AI-ASASIYYA: Journal Of Basic Education Vol. 01 No. 02 Hal. 34-46. Tersedia Pada : http://journal.umpo.ac.id/index.php/al-asasiyya/article/view/683/0.

Setyosari, Punaj. 2015. Metode Pendidikan \& Pengembangan. Jakarta: Prenada media Group.

Sufairoh. 2016. Pendekatan Saintifik \& Model Pembelajaran K-13. Jurnal Pendidikan Profesional, Vol. 5 No. 3 Hal. 116-125. Tersedia Pada : http://www.jurnalpendidikanprofesional.com/index.php/JPP/article/download/186/pdf_1 04.

Sugiyono.2012. Metode Penelitian Pendidikan.Bandung: Alfabeta.

Wisudawati, Asih Widi. Sulistyowati,Eka.2015. Metodologi Pembelajaran IPA. Jakarta: Bumi Aksara.

Yusuf, Muri.2015.Asessmen Dan Evaluasi Pendidikan. Jakarta:Prenadamedia Group. 